\title{
Challenges in extracorporeal membrane oxygenation
}

Citation for published version (APA):

Martucci, G. (2022). Challenges in extracorporeal membrane oxygenation: Precision management to improve survival. [Doctoral Thesis, Maastricht University]. Maastricht University. https://doi.org/10.26481/dis.20220117gm

Document status and date:

Published: 01/01/2022

DOI:

10.26481/dis.20220117gm

Document Version:

Publisher's PDF, also known as Version of record

\section{Please check the document version of this publication:}

- A submitted manuscript is the version of the article upon submission and before peer-review. There can be important differences between the submitted version and the official published version of record.

People interested in the research are advised to contact the author for the final version of the publication, or visit the DOI to the publisher's website.

- The final author version and the galley proof are versions of the publication after peer review.

- The final published version features the final layout of the paper including the volume, issue and page numbers.

Link to publication

\footnotetext{
General rights rights.

- You may freely distribute the URL identifying the publication in the public portal. please follow below link for the End User Agreement:

www.umlib.nl/taverne-license

Take down policy

If you believe that this document breaches copyright please contact us at:

repository@maastrichtuniversity.nl

providing details and we will investigate your claim.
}

Copyright and moral rights for the publications made accessible in the public portal are retained by the authors and/or other copyright owners and it is a condition of accessing publications that users recognise and abide by the legal requirements associated with these

- Users may download and print one copy of any publication from the public portal for the purpose of private study or research.

- You may not further distribute the material or use it for any profit-making activity or commercial gain

If the publication is distributed under the terms of Article $25 \mathrm{fa}$ of the Dutch Copyright Act, indicated by the "Taverne" license above, 


\section{Chapter 12}

Summary

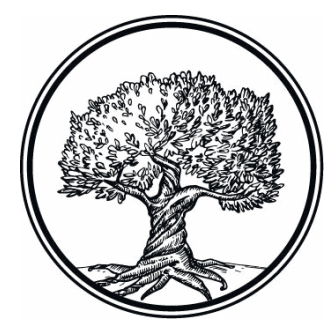


Chapter 1. This chapter is a general introduction to the entire thesis. Here the topic of the changing discipline of ECMO is introduced, and the several unresolved questions in this field are reported, as well as an outline of the relevant studies included.

Chapter 2. In this chapter we present a single-center experience in the management of anticoagulation and transfusions in V-V ECMO. Here is presented a protocol for anticoagulation based on low-dose heparin, low anticoagulation range based on frequent measurement of activated partial thromboplastin time and a tolerance for lower hemoglobin levels, considering the transfusion a medical act that should be considered only in the wider context of the patient's condition and not just related to a trigger. The results showed one of the lowest available mean dosages of heparin infusion during ECMO, and a significant overall survival, which was significantly better in patients with lower amount of PRBC transfused.

Chapter 3. This study is a single center retrospective analysis of different effects of changing some part of the ECMO circuit. In this case we compare a group with a standard cannulation and circuit and the following group where shorter bioline-coated cannulas were applied. In this case we saw a significantly lower amount of transfusions, and a trend toward shorter ECMO stays in the bioline group, with an associated reduction in costs despite the more expensive cannulas.

Chapter 4. In this chapter we illustrate the results of a voluntary Web-based survey, endorsed by the European Society of Intensive Care Medicine, on the hemoglobin trigger for transfusions worldwide. Among 447 respondents, the majority did not use a definitive hemoglobin trigger, but when they used one it was higher than for other critically ill patients. Interestingly, there was a significant difference in the hemoglobin trigger adopted according to the volume of the centers, with higher volume centers tolerating lower hemoglobin values.

Chapter 5. Limb ischemia is a possible complication of peripheral V-A ECMO. In this review we illustrate the incidence and the risk factors for this complication, analyzing the wide range of the recent relevant literature. The main conclusion is that in V-A ECMO, limb ischemia should be prevented and eventually rapidly suspected and treated with a protocolized approach. The mainstay to prevent limb ischemia seems to be a distal perfusion cannula and a dual flow cannula. We also present operative flow-charts to monitor and treat limb ischemia gathered from data in the literature.

Chapter 6. Gastrointestinal bleeding is one of the more frequent complications in critically ill patients under ECMO, and is burdened with higher mortality. In this single center retrospective study we demonstrate that advanced endoscopy management, also including the Hemospray for hemostasis, can contribute to reach a mortality rate similar to the other cohorts of patients on V-V ECMO, despite the increased use of blood products. 
Chapter 7. In this narrative review, the use of antithrombin in ECMO is explored. Antithrombin had its day in the sun in the previous decade in cases of sepsis, since it is a relevant link between coagulation and the inflammatory cascade. In fact, beyond being the effector needed for heparin anticoagulation activity, it has anti-inflammatory properties, and is able to protect the endothelium, both activities eventually positive during the ECMO course. High costs, the risk associated with human blood products, and the absence of standard evidence in RCT have restrained its diffusion.

Chapter 8. This is a case series of intra-abdominal hypertension developed in three patients under V-V ECMO support. The case series highlight the issue of intra-abdominal hypertension during ECMO and its effect on the ability of dreinage cannula, describe a novel non-invasive approach through advanced endoscopy (total water-assisted colonoscopy) and illustrate a systematic review of the literature on the topic. A practical flow-chart to approach early and non-invasively the issue of intra-abdominal hypertension with its peculiar effects in ECMO has been also proposed.

Chapter 9. In a pilot study the potential circulating miRNA signature in patients affected with ARDS and lately supported on ECMO is illustrated with the aim of better characterize ARDS patients in their severity and, possibly, in their prognosis. As promising results, the blood levels of 13 miRNAs, strongly related to biological pathways possibly associated with ARDS, are altered in patients with severe ARDS, and may offer diagnostic value as well as contribute to ARDS stratification.

Chapter 10. This chapter is a general discussion of the entire work, were the main topics are summarized and considerations of precision medicine and precision management are illustrated. 


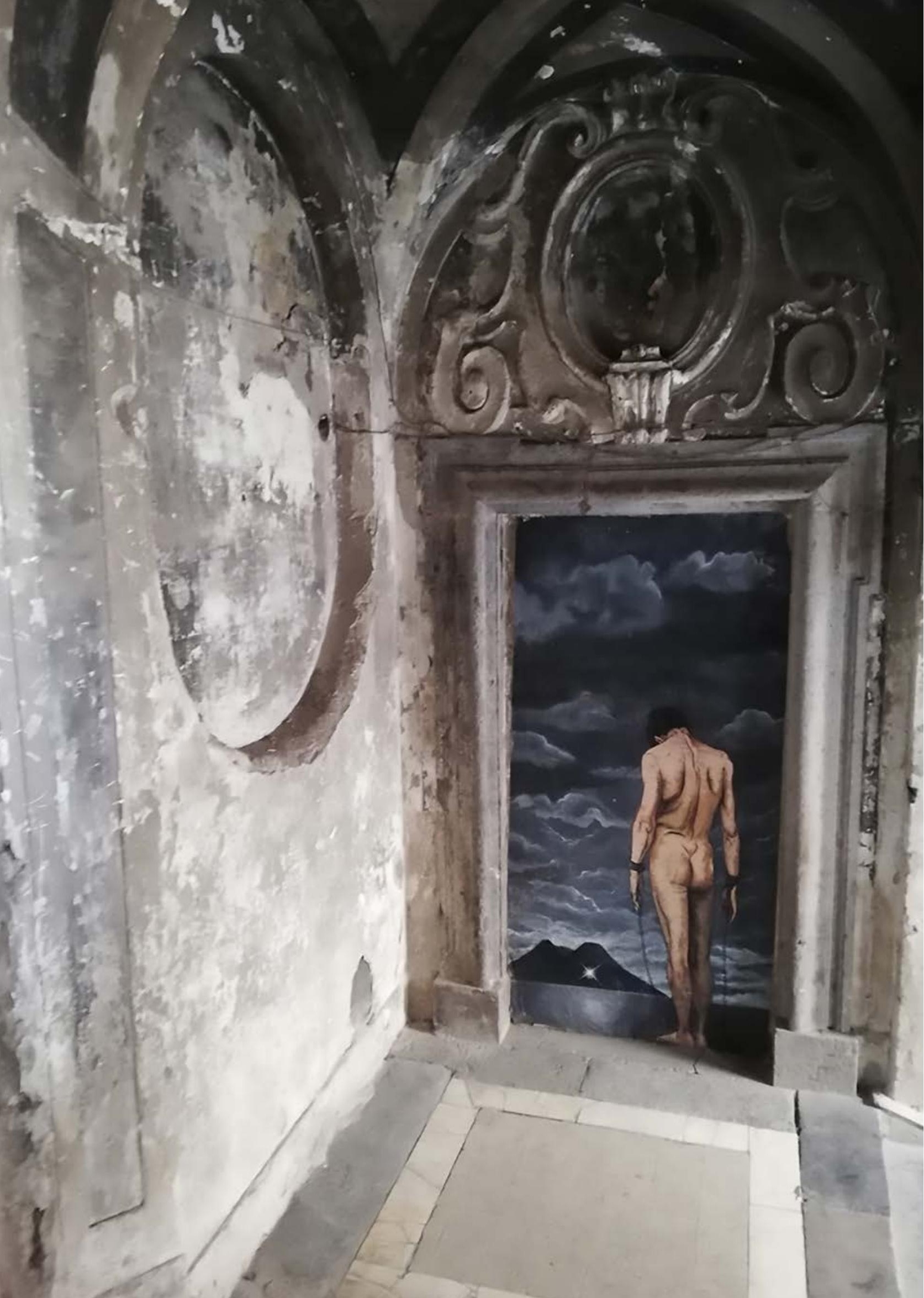




\section{Chapter 13}

Samenvatting

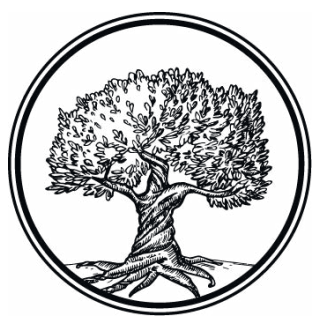


Hoofdstuk 1. Dit hoofdstuk is een algemene inleiding op het gehele proefschrift. Hier wordt het onderwerp van de veranderende discipline van ECMO geïntroduceerd en worden de verschillende onopgeloste vragen op dit gebied gerapporteerd, evenals een overzicht van de relevante opgenomen onderzoeken.

Hoofdstuk 2. In dit hoofdstuk presenteren we een single-center ervaring in het beheer van antistolling en transfusies in V-V ECMO. Hier wordt een protocol gepresenteerd voor antistolling op basis van een lage dosis heparine, een laag antistollingsbereik gebaseerd op frequente meting van de geactiveerde partiële tromboplastinetijd en een tolerantie voor lagere hemoglobinespiegels, aangezien de transfusie een medische handeling is die alleen in de bredere context van de toestand van de patiënt en niet alleen gerelateerd aan een trigger. De resultaten lieten een van de laagste beschikbare gemiddelde doseringen van heparine-infusie tijdens ECMO zien, en een significante algehele overleving, die significant beter was bij patiënten met een lagere hoeveelheid PRBC-transfusies.

Hoofdstuk 3. Deze studie is een retrospectieve analyse vanuit één centrum van verschillende effecten van het veranderen van een deel van het ECMO-circuit. In dit geval vergelijken we een groep met een standaard canulatie en circuit en de volgende groep waar kortere bioline-gecoate canules werden aangebracht. In dit geval zagen we een significant lager aantal transfusies, en een trend naar kortere ECMO-verblijven in de biolinegroep, met een bijbehorende kostenverlaging ondanks de duurdere canules.

Hoofdstuk 4. In dit hoofdstuk illustreren we de resultaten van een vrijwillige webgebaseerde enquête, goedgekeurd door de European Society of Intensive Care Medicine, naar de hemoglobine-trigger voor transfusies wereldwijd. Van de 447 respondenten gebruikte de meerderheid geen definitieve hemoglobine-trigger, maar wanneer ze er een gebruikten, was deze hoger dan bij andere ernstig zieke patiënten. Interessant genoeg was er een significant verschil in de hemoglobine-trigger die werd aangenomen in overeenstemming met het volume van de centra, waarbij centra met een hoger volume lagere hemoglobinewaarden tolereerden.

Hoofdstuk 5. Ledemaatischemie is een mogelijke complicatie van perifere V-A ECMO. In deze review illustreren we de incidentie en de risicofactoren voor deze complicatie, waarbij we het brede scala van de recente relevante literatuur analyseren. De belangrijkste conclusie is dat bij V-A ECMO ischemie van de ledematen moet worden voorkomen en uiteindelijk snel moet worden vermoed en behandeld met een geprotocolleerde benadering. De steunpilaar om ischemie van de ledematen te voorkomen, lijkt een distale perfusiecanule en een canule met dubbele stroom te zijn. We presenteren ook operatieve stroomdiagrammen om ischemie van ledematen te volgen en te behandelen die zijn verzameld uit gegevens in de literatuur. 
Hoofdstuk 6. Gastro-intestinale bloeding is een van de meest voorkomende complicaties bij ernstig zieke patiënten onder ECMO, en gaat gepaard met een hogere mortaliteit. In deze retrospectieve studie in één centrum laten we zien dat geavanceerd endoscopiebeheer, waaronder ook de Hemospray voor hemostase, kan bijdragen aan het bereiken van een sterftecijfer dat vergelijkbaar is met dat van de andere cohorten van patiënten op V-V ECMO, ondanks het toegenomen gebruik van bloedproducten.

Hoofdstuk 7. In deze narratieve review wordt het gebruik van antitrombine bij ECMO onderzocht. Antitrombine had zijn dag in de zon in het vorige decennium in gevallen van sepsis, omdat het een relevante link is tussen coagulatie en de inflammatoire cascade. In feite is het niet alleen de effector die nodig is voor de antistollingsactiviteit van heparine, het heeft ook ontstekingsremmende eigenschappen en kan het endotheel beschermen, beide activiteiten zijn uiteindelijk positief tijdens de ECMO-kuur. Hoge kosten, het risico verbonden aan menselijke bloedproducten en het ontbreken van standaard bewijs in RCT hebben de verspreiding ervan beperkt.

Hoofdstuk 8. Dit is een casus van intra-abdominale hypertensie ontwikkeld bij drie patiënten onder VV ECMO ondersteuning. De casusreeks belicht de kwestie van intra-abdominale hypertensie tijdens ECMO en het effect ervan op het vermogen van een canule voor ontreiniging, beschrijft een nieuwe niet-invasieve benadering door middel van geavanceerde endoscopie (totale waterondersteunde colonoscopie) en illustreert een systematische review van de literatuur over de onderwerp. Er is ook een praktisch stroomschema voorgesteld om de kwestie van intra-abdominale hypertensie met zijn eigenaardige effecten bij ECMO vroegtijdig en niet-invasief te benaderen.

Hoofdstuk 9. In een pilotstudie wordt de potentiële circulerende miRNA-signatuur bij patiënten met ARDS en recent ondersteund door ECMO geillustreerd met het doel ARDS-patiënten beter te karakteriseren in hun ernst en mogelijk in hun prognose. Als veelbelovende resultaten zijn de bloedspiegels van 13 miRNA's, sterk gerelateerd aan biologische routes die mogelijk geassocieerd zijn met ARDS, veranderd bij patiënten met ernstige ARDS, en kunnen ze zowel diagnostische waarde bieden als bijdragen aan ARDS-stratificatie.

Hoofdstuk 10. Dit hoofdstuk is een algemene bespreking van het hele werk, waarin de belangrijkste onderwerpen worden samengevat en overwegingen van precisiegeneeskunde en precisiemanagement worden geillustreerd. 


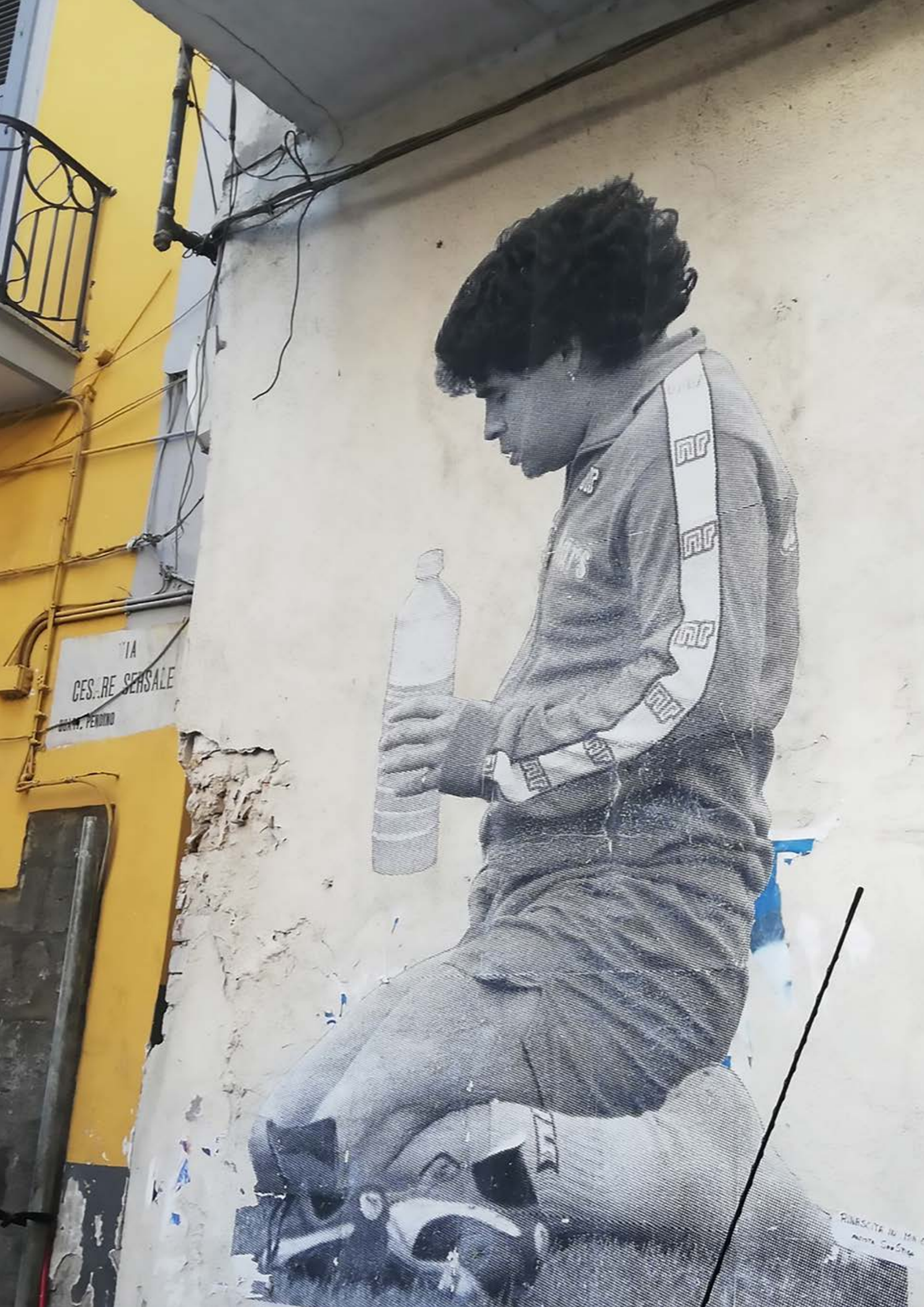

